\title{
UCRL-PROC-228001
}

LAWRENCE LIVERMORE N A T IO N A L LABORATORY

\section{Crevice Repassivation Potential of Alloy 22 in High-Nitrate Dust Deliquescence Type Environments}

T. Lian, G. E. Gdowski, P. D. Hailey, R. B. Rebak

February 13,2007

2007 ASME Pressure Vessels and Piping Division Conference San Antonio, TX, United States July 22, 2007 through July 26, 2007 
This document was prepared as an account of work sponsored by an agency of the United States Government. Neither the United States Government nor the University of California nor any of their employees, makes any warranty, express or implied, or assumes any legal liability or responsibility for the accuracy, completeness, or usefulness of any information, apparatus, product, or process disclosed, or represents that its use would not infringe privately owned rights. Reference herein to any specific commercial product, process, or service by trade name, trademark, manufacturer, or otherwise, does not necessarily constitute or imply its endorsement, recommendation, or favoring by the United States Government or the University of California. The views and opinions of authors expressed herein do not necessarily state or reflect those of the United States Government or the University of California, and shall not be used for advertising or product endorsement purposes. 


\title{
Proceedings of PVP2006 \\ 2007 ASME Pressure Vessels and Piping Division Conference July 22-26, 2007, San Antonio, Texas \\ PVP200726164
}

\section{CREVICE REPASSIVATION POTENTIAL OF ALLOY 22 IN HIGH-NITRATE \\ DUST DELIQUESCENCE TYPE ENVIRONMENTS}

\author{
Tiangan Lian \\ Gregory E. Gdowski \\ Phillip D. Hailey \\ Raul B. Rebak \\ Lawrence Livermore National Laboratory
7000 East Ave, L-631
Livermore, California, 94550 USA
}

\section{ABSTRACT}

The nitrate ion $\left(\mathrm{NO}_{3}^{-}\right)$is an inhibitor for crevice corrosion of Alloy 22 (N06022) in chloride $\left(\mathrm{Cl}^{-}\right)$aqueous solutions. Naturally formed electrolytes may contain both chloride and nitrate ions. The higher the ratio $\mathrm{R}=\left[\mathrm{NO}_{3}^{-}\right] /\left[\mathrm{Cl}^{-}\right]$in the solution the stronger the inhibition of crevice corrosion. Atmospheric desert dust contains both chloride and nitrate salts, generally based on sodium $\left(\mathrm{Na}^{+}\right)$and potassium $\left(\mathrm{K}^{+}\right)$. Some of these salts may deliquescence at relatively low humidity at temperatures on the order of $150^{\circ} \mathrm{C}$ and higher. The resulting deliquescent brines are highly concentrated and especially rich in nitrate. Electrochemical tests have been performed to explore the anodic behavior of Alloy 22 in high chloride high nitrate electrolytes at temperatures as high as $150^{\circ} \mathrm{C}$ at ambient atmospheres. Naturally formed brines at temperatures higher than $120^{\circ} \mathrm{C}$ do not induce crevice corrosion in Alloy 22 because they contain high levels of nitrate. The inhibitive effect of nitrate on crevice corrosion is still active for temperatures higher than $100^{\circ} \mathrm{C}$.

Keywords: N06022, Sodium Chloride, Potassium Nitrate, High Temperature, Deliquescence

\section{INTRODUCTION}

Alloy 22 (N06022) is a nickel based alloy designed to be resistant to all forms of corrosion. Alloy 22 contains $56 \%$ nickel (Ni), chromium (Cr), molybdenum (Mo), tungsten (W) and iron $(\mathrm{Fe})$. The range in composition is given in ASTM B 575. ${ }^{1}$ Because of its high level of $\mathrm{Cr}$, Alloy 22 remains passive in most industrial environments and therefore it has an exceptionally low dissolution rate. ${ }^{2-6}$ The combined presence of Cr, Mo and W imparts Alloy 22 with high resistance to localized corrosion such as pitting corrosion and stress corrosion cracking even in hot high chloride $\left(\mathrm{Cl}^{-}\right)$solutions. ${ }^{7-12}$ Alloy 22 may suffer localized corrosion such as crevice corrosion when it is anodically polarized in chloride containing solutions. ${ }^{8-10,13-15}$ The presence of nitrate $\left(\mathrm{NO}_{3}^{-}\right)$and other oxyanions in the solution minimizes or eliminates the susceptibility of Alloy 22 to crevice corrosion. ${ }^{8-10,16-23}$ The value of the ratio $\mathrm{R}\left(\mathrm{R}=\left[\mathrm{NO}_{3}^{-}\right] /\left(\left[\mathrm{Cl}^{-}\right]\right)\right.$has a strong effect of the susceptibility of Alloy 22 to crevice corrosion. ${ }^{16-23}$ The higher the nitrate to chloride ratio the stronger the inhibition by nitrate. Most of the work on the susceptibility of Alloy 22 to crevice corrosion was at temperatures of $100^{\circ} \mathrm{C}$ and below. One study contained the behavior of Alloy 22 at temperatures up to $160^{\circ} \mathrm{C}$ in highly concentrated calcium based chloride and nitrate brines. ${ }^{24}$ It was reported that the inhibiting effect of nitrate for crevice corrosion is also valid up to temperatures of $160^{\circ} \mathrm{C}$. $^{24}$

Corrosion at the repository site may occur only in the presence of water. There are two possible sources of water that may contact the container at the repository site, seepage from the drift walls; or, deliquescence of salt and dust that may have accumulated during the initial dry periods. Deliquescence of salt mixtures will be the primary source of aqueous solution that may contact and react with waste package surfaces at temperatures above that for boiling of water (during the repository initial thermal period).

Highly soluble salts such as potassium nitrate can produce concentrated solutions that will remain liquid to temperatures higher than $150^{\circ} \mathrm{C}$ at ambient pressure. ${ }^{25}$ Chloride and nitrate salts based on the metals potassium and sodium are contained in dust that may be present at the Yucca Mountain repository site. $^{26}$ 
The majority of the aqueous solutions that are predicted to form on the waste packages due to dust deliquescence will consist of chloride and nitrate salts of sodium and potassium, and, in some cases, calcium. ${ }^{25-26}$ Recent work indicates that deliquescence of these salt mixtures can occur at temperatures in excess of $180^{\circ} \mathrm{C}$ (Figure 1), even at a low relative humidity of $10-20 \%{ }^{25,26}$

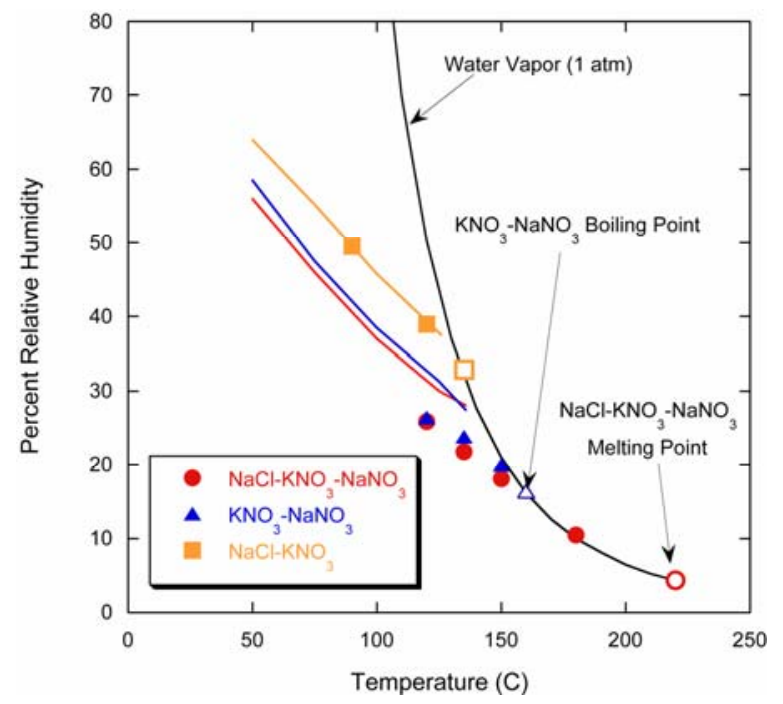

Figure 1. Na-K brines formed by deliquescence ${ }^{25-26}$

The purpose of the current work was to examine the anodic behavior of Alloy 22 in highly concentrated brines at temperatures $100^{\circ} \mathrm{C}$ and higher. The studies were performed in solutions based mainly on sodium and potassium because these cations are present in the dust. Tests were performed under fully immersed conditions, with unlimited access of brine to the corroding specimen. The volume of concentrated solutions that may form by deliquescence of dust will be small. ${ }^{26}$

\section{EXPERIMENTAL TECHNIQUE}

The specimens of Alloy 22 (N06022) were prism crevice assemblies (PCA) (Figure 2) in the as-welded (ASW) condition. The specimens were machined from welded 1.25inch thick plates $(\sim 32 \mathrm{~mm})$. Table 1 shows the chemical composition of the heats for the base plate and the welding wire. The plates were welded using gas tungsten arc welding (GTAW) from both sides of the plate using the double V groove technique. The exposed surface area for the PCA specimens was $14.06 \mathrm{~cm}^{2}$. This surface area did not include the area covered by the crevice formers (CF), which was approximately $1.5 \mathrm{~cm}^{2}$. The PCA had a mounting mechanism for the connecting rod explained in ASTM G 5 (Figure 2). ${ }^{27}$ Crevice formers (CF) were mounted on both sides of the specimen. Each crevice former consisted of a washer made of a ceramic material containing 12 crevicing spots or teeth with gaps in between the teeth (ASTM G 78). ${ }^{27}$ Before mounting the $\mathrm{CF}$ onto the metallic specimens, they were covered with PTFE tape to ensure a tight crevicing gap between the CF and the specimens. The specimens had a ground surface finish of 600-grit paper.

\section{Table 1. Heat and Composition Of the Tested Specimens}

\begin{tabular}{|l|l|}
\hline $\begin{array}{c}\text { Heat - Manufacturer } \\
\text { Of Alloy 22 }\end{array}$ & \multicolumn{1}{|c|}{ Composition } \\
\hline & \\
\hline Base Plate by Haynes & $55.29 \mathrm{Ni}, 21.23 \mathrm{Cr}$, \\
International & $13.37 \mathrm{Mo}, 2.93 \mathrm{~W}$, \\
Heat 2277-0-3183 & $3.65 \mathrm{Fe}, 1.7 \mathrm{Co}$, \\
& $0.23 \mathrm{Mn}, 0.14 \mathrm{~V}$ \\
\hline Weld Wire by Inco & $59.31 \mathrm{Ni}, 20.44 \mathrm{Cr}$, \\
Alloys & $14.16 \mathrm{Mo}, 3.07 \mathrm{~W}$, \\
Heat XX1829BG & $2.2 \mathrm{Fe}, 0.21 \mathrm{Mn}, 0.15 \mathrm{Cu}$ \\
\hline
\end{tabular}

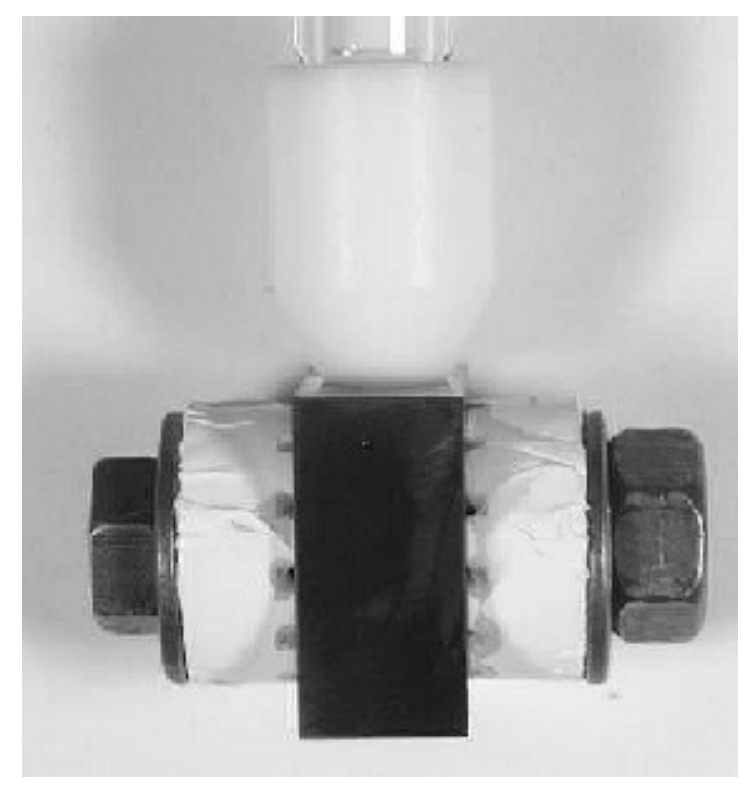

Figure 2. Assembled PCA Specimen

Two different sets of electrochemical tests were performed: (1) Monitoring of the corrosion potential for 24 hours, followed by either a (2) Cyclic Potentiodynamic Polarization (CPP) (ASTM G 61) ${ }^{27}$ or a (3) TsujikawaHisamatsu Electrochemical (THE) test. ${ }^{15}$ 
Several types of electrolytes were used, from pure chloride to pure nitrate solutions. Table 2 shows a list of tested electrolytes and tested temperatures. Most of the electrolytes were highly concentrated to avoid boiling at ambient pressure. The electrolytes were deaerated with purified nitrogen. The gas stream $\left(\mathrm{N}_{2}\right)$ exited the vessel through a condenser to avoid evaporation of the electrolyte. It is not known how the condensation (refluxing) could have affected the $\mathrm{pH}$ of the electrolyte. The volume of the solution used for each test was $900 \mathrm{~mL}$. Potentials were monitored using saturated silver chloride electrodes [SSC] through a Luggin capillary. The capillary was filled with $5 \mathrm{M} \mathrm{CaCl}_{2}$ solution because most of the tested solutions are not liquid at ambient temperatures. The reference electrode was kept near room temperature using a jacketed electrode holder through which cooled water was recirculated. The potentials in this paper are reported in the saturated silver chloride scale [SSC]. At ambient temperature, the SSC scale is $199 \mathrm{mV}$ more positive than the normal hydrogen electrode (NHE).

\section{EXPERIMENTAL RESULTS AND DISCUSSION}

\section{Evolution of the Corrosion Potential}

Figure 3 shows the evolution of the $\mathrm{E}_{\text {corr }}$ for four Alloy 22 specimens as a function of the immersion time in deaerated brines at $125^{\circ} \mathrm{C}$. Two specimens were immersed in $1 \mathrm{~m} \mathrm{CaCl}_{2}+$ $10 \mathrm{~m} \mathrm{Ca}\left(\mathrm{NO}_{3}\right)_{2}(\mathrm{R}=10)$ and two specimens were immersed in $4 \mathrm{~m} \mathrm{KCl}+21 \mathrm{~m} \mathrm{KNO}_{3}+21 \mathrm{~m} \mathrm{NaNO}_{3}(\mathrm{R}=10.5)$. The open circuit potential was taken every 20 seconds. The $\mathrm{Ca}$ based brine has a concentration by weight (solute/solution) of $64 \%$ and the $\mathrm{Na}+\mathrm{K}$ brine has a concentration of $81 \%$. Even though the ratio $\mathrm{R}$ of the concentration of nitrate over chloride was practically the same, Figure 3 shows a completely different behavior of the corrosion potential for Alloy 22 depending if the solution was based on $\mathrm{Na}+\mathrm{K}$ or based on $\mathrm{Ca}$. The open circuit potential for Alloy 22 in the Ca based brines increased rapidly in the first two hours of exposure and then more gradually for the rest of the exposure time. After only 24immersion, the $\mathrm{E}_{\text {corr }}$ of Alloy 22 in the Ca brines is on the order of $+600 \mathrm{mV} \mathrm{SSC}$, a potential that can be considered high (Table 2). The total change in potential in this relatively short time of 24 hours is more than $700 \mathrm{mV}$. In the $\mathrm{Na}+\mathrm{K}$ brine, the open circuit potential of Alloy 22 slowly decreased as a function of time and after 18-h immersion it was on the order of $-450 \mathrm{mV}$ (see also Table 2). The total change since immersion is less than $50 \mathrm{mV}$. It is not clear at this moment why Alloy 22 behaves so differently in these two types of electrolytes. It is likely that it is related to the hydrolysis properties of the metal cations in the electrolyte, which may control the $\mathrm{pH}$ of the electrolyte in contact with the alloy.

Figure 4 shows comparatively the evolution of the open circuit potential for Alloy 22 in pure chloride solutions of the same concentration ( 8 molal chloride) at $110^{\circ} \mathrm{C}$. Again, as shown at $125^{\circ} \mathrm{C}$ for the chloride plus nitrate brines (Figure 3), the short-term corrosion potential evolution is different depending if the brine is $\mathrm{Ca}$ or $\mathrm{Na}+\mathrm{K}$ based. In the $\mathrm{Ca}$ brine the corrosion potential increased as the time increased and it changed more than $100 \mathrm{mV}$ in 24 hours. In the $\mathrm{Na}+\mathrm{K}$ brines, the open circuit potential tended to decrease as the immersion time increased. In one of the specimens (KE0691) the decrease in potential was only $10 \mathrm{mV}$.

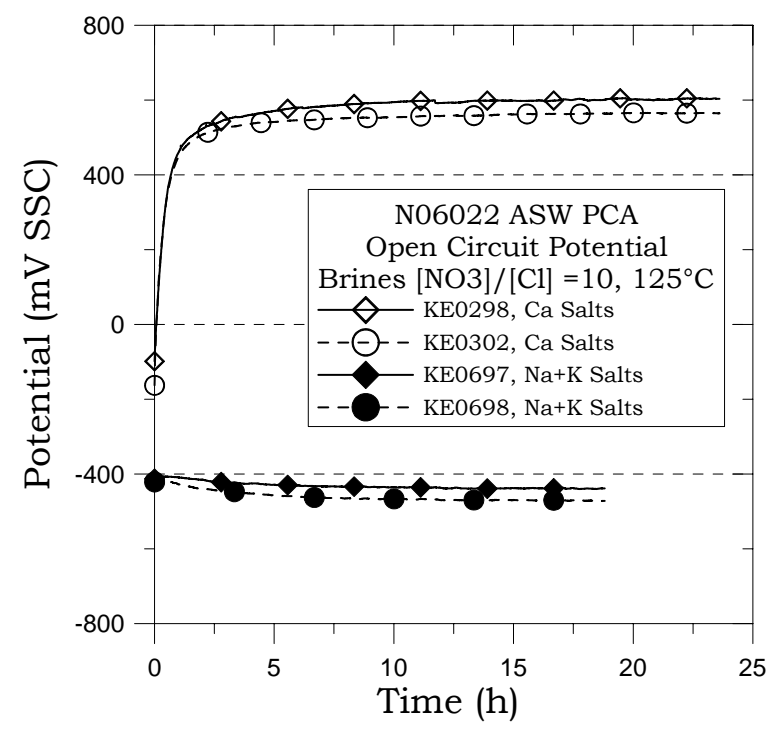

Figure 3. Corrosion potential vs. time in $\mathrm{Ca}$ and $\mathrm{Na}+\mathrm{K}$ brines at $125^{\circ} \mathrm{C}$

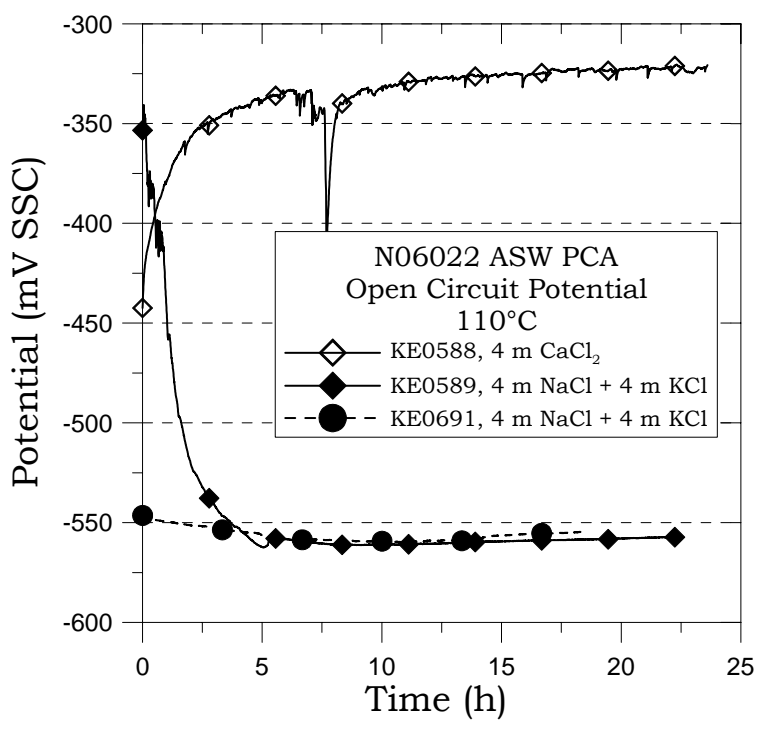

Figure 4. Corrosion potential vs. time in $\mathrm{Ca}$ and $\mathrm{Na}+\mathrm{K}$ brines at $110^{\circ} \mathrm{C}$ 
Figure 5 shows corrosion potential at the end of the shorttime exposure of 24 hours for all the specimens tested at $125^{\circ} \mathrm{C}$ (Table 2). Figure 5 shows that for even up to $R=100$, the corrosion potential of Alloy 22 in the $\mathrm{Na}+\mathrm{K}$ brines was not greatly affected by the amount of nitrate in solution. However, in the $\mathrm{Ca}$ based brine, as the ratio $\mathrm{R}$ increased the corrosion potential increased. The short-term Ecorr of Alloy 22 in $\mathrm{Ca}$ based brines at $110^{\circ} \mathrm{C}$ was more than $800 \mathrm{mV}$ higher than the Ecorr in the $\mathrm{Na}+\mathrm{K}$ brines.

The values of corrosion potential in Table 2 and in Figures 3-5 are for comparative purposes only and they do not intend to represent the long-term behavior of Alloy 22 in these brines.

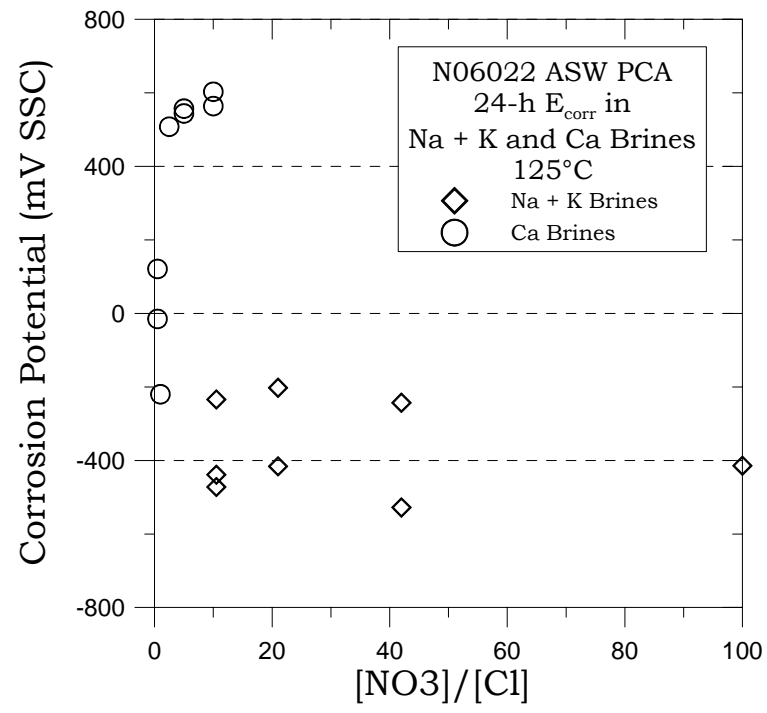

Figure 5. $\mathrm{E}_{\text {corr }}$ of Alloy 22 in $\mathrm{Ca}$ and $\mathrm{Na}+\mathrm{K}$ brines at $110^{\circ} \mathrm{C}$

\section{Effect of Solution Composition on the Cyclic Potentiodynamic Behavior at $110^{\circ} \mathrm{C}$}

Figure 6 shows the cyclic potentiodynamic polarization (CPP) curves for Alloy 22 in three different electrolyte solutions at $110^{\circ} \mathrm{C}$ (Table 2). The base concentration of the solution is $8 \mathrm{~m}$ chloride $(4 \mathrm{~m} \mathrm{NaCl}+4 \mathrm{~m} \mathrm{KCl})$. Figure 6 shows that the breakdown potential increased as the amount of nitrate in the electrolyte solution increased. In the pure $\mathrm{Cl}$ solution for a ratio $\mathrm{R}=0$ the breakdown potential (E20) for specimen KE0691 was $49 \mathrm{mV}$ SSC (Table 2). For specimen KE0687 for a solution with a ratio $\mathrm{R}=0.1$, the E20 increased to $361 \mathrm{mV}$ SSC and for specimen KE0287 for $\mathrm{R}=0.5$ the E20 was 621 $\mathrm{mV}$ SSC. The repassivation potential ER1 also increased when the amount of nitrate in the electrolyte increased (Table 2). For specimen $\mathrm{KE0691}(\mathrm{R}=0) \mathrm{ER} 1$ was $-184 \mathrm{mV} \mathrm{SSC}$, for specimen KE0687 $(\mathrm{R}=0.1)$ ER1 was $-46 \mathrm{mV} \mathrm{SSC}$ and for specimen KE0287 $(\mathrm{R}=0.5)$ ER1 was $327 \mathrm{mV}$ SSC. Figure 6 also shows that both for $\mathrm{R}=0$ and $\mathrm{R}=0.1$ the reverse polarization curve showed a hysteresis, often an indication of localized corrosion (crevice corrosion). When the ratio $\mathrm{R}$ was 0.5 , the reverse polarization did not show hysteresis, often an indication of absence of localized corrosion. Figure 7 shows that specimen KE0691 after testing in pure 8 molal chloride solution at $110^{\circ} \mathrm{C}$, exhibited crevice corrosion. On the other hand, specimen KE0580 tested in a solution containing 8 molal chloride and 4 molal nitrate $(\mathrm{R}=0.5)$, was free from crevice corrosion (Figure 8), even though specimen KE0580 was anodically polarized to much higher potentials and for a longer time than specimen KE0691.

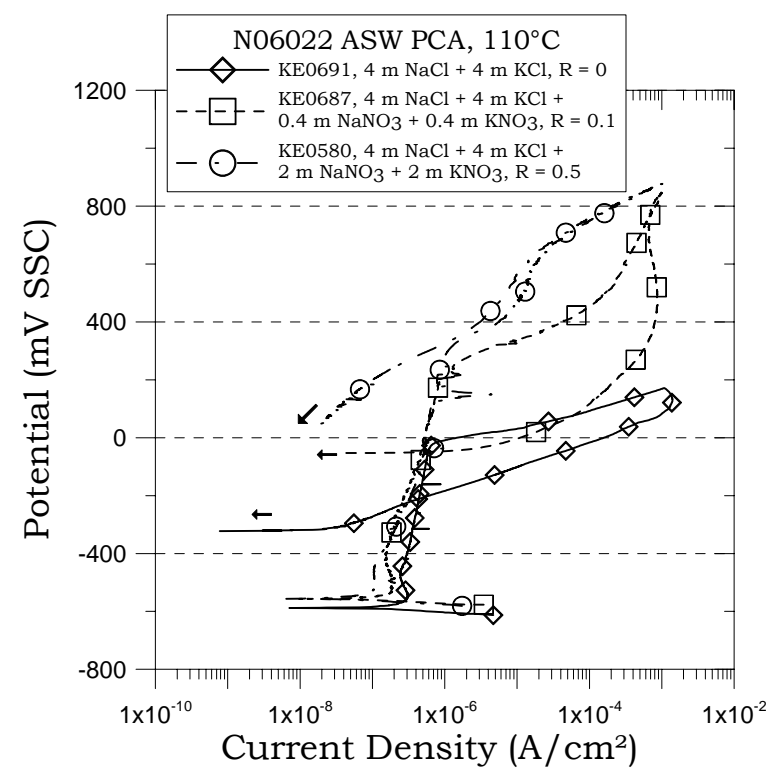

Figure 6. Cyclic Potentiodynamic Polarization of Alloy 22 in $\mathrm{Cl}^{-}$and $\mathrm{Cl}^{-}+\mathrm{NO}_{3}{ }^{-}$brines at $110^{\circ} \mathrm{C}$

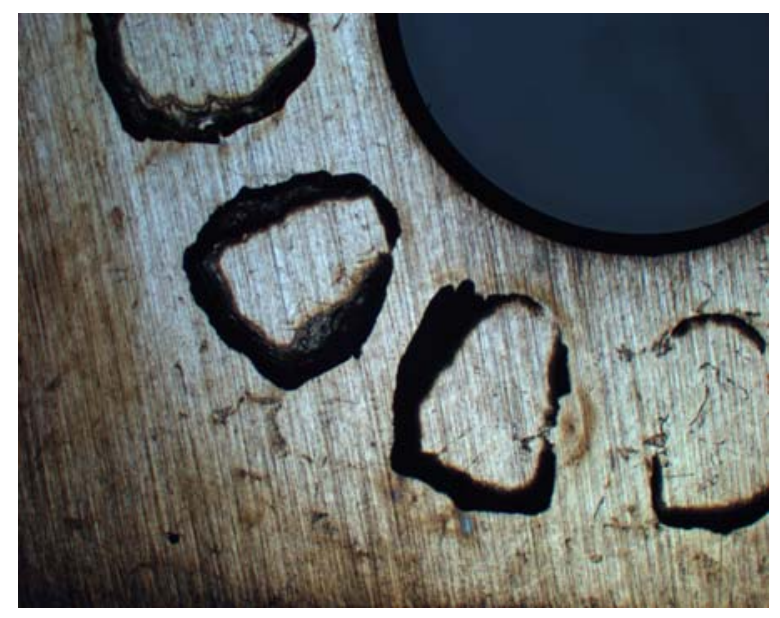

Figure 7. KE0691 after CPP test Crevice corrosion is observed 


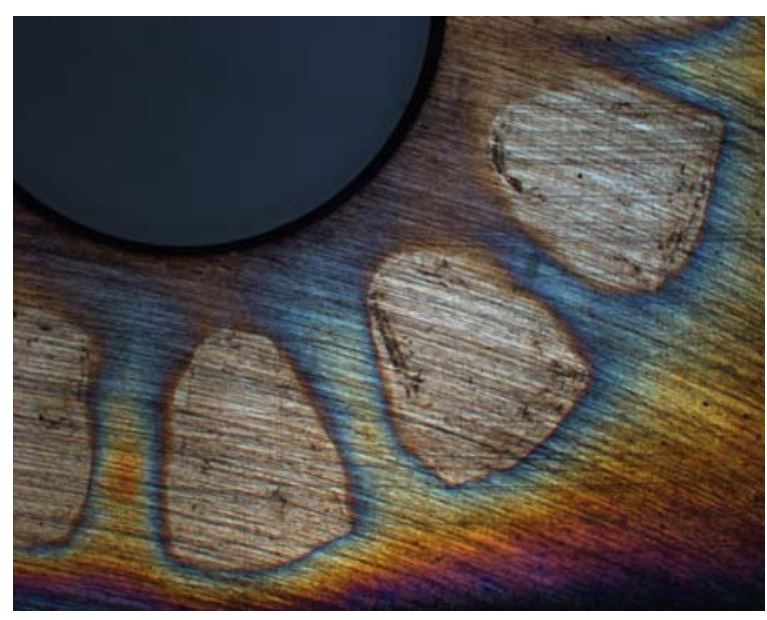

Figure 8. KE0580 after CPP test No crevice corrosion

Results from Figures 6-8 clearly shows the inhibiting effect of nitrate on the crevice corrosion susceptibility of Alloy 22, even in highly concentrated brines at $110^{\circ} \mathrm{C}$.

\section{Cyclic Polarization at Higher Temperatures}

Figure 9 shows the anodic behavior of Alloy 22 at $125^{\circ} \mathrm{C}$ in highly concentrated nitrate solutions. Specimen KE0697 was tested in a brine containing nitrate and chloride to a ratio $\mathrm{R}$ of 10.5 and Specimen KE0281 was tested in a pure nitrate solution $(\mathrm{R}=\infty)$. The behavior of Alloy 22 was practically the same in both solutions. The breakdown potentials E20 and repassivation potentials ER1 were high (775 and $625 \mathrm{mV}$ SSC for KE0697 and 783 and $686 \mathrm{mV}$ for KE0281) (Table 2). The high values of breakdown potentials suggest an increase in current due to the decomposition of water. The reverse scan occurred without hysteresis or with a negative hysteresis suggesting the absence of localized corrosion. Figure 10 shows that both specimens were free of localized corrosion after the tests.

Figure 11 shows the anodic behavior of Alloy 22 at $140^{\circ} \mathrm{C}$ and $150^{\circ} \mathrm{C}$. The behavior of Alloy 22 was practically the same in both solutions and temperatures. The breakdown potentials E20 were $785 \mathrm{mV} \mathrm{SSC}$ for KE0700 and $806 \mathrm{mV} \mathrm{SSC} \mathrm{for}$ KE0284. Both CPP curves exhibited negative hysteresis in the reverse scan. None of the specimens suffered crevice corrosion in spite of the high applied potential (Figure 12).

\section{Repassivation Potentials}

Figure 13 shows the repassivation potentials for Alloy 22 at $110^{\circ} \mathrm{C}$ in pure chloride and low nitrate concentration electrolytes $(\mathrm{R} \leq 1)$. There are two type of repassivation potentials represented, one is ER1 from the CPP tests (circles) and the other CRP from the THE tests (squares) (Table 2). The line joins the average values of the ER1 potentials. Figure 13 shows that both type of tests (CPP and THE) yield comparable values of repassivation potentials. The repassivation potential was approximately $-200 \mathrm{mV} \mathrm{SSC}$ in the pure chloride solution $(\mathrm{R}=0)$ and climbed rapidly as the nitrate concentration was increased. At a ratio $\mathrm{R}=0.5$ the repassivation potential was approximately $400 \mathrm{mV} \mathrm{SSC}$, that is, $600 \mathrm{mV}$ higher than in pure chloride solutions. The repassivation potential was higher than $450 \mathrm{mV}$ SSC for a ratio $\mathrm{R}=1$. Figure 13 shows the strong effect of nitrate as an inhibitor of crevice corrosion in Alloy 22.

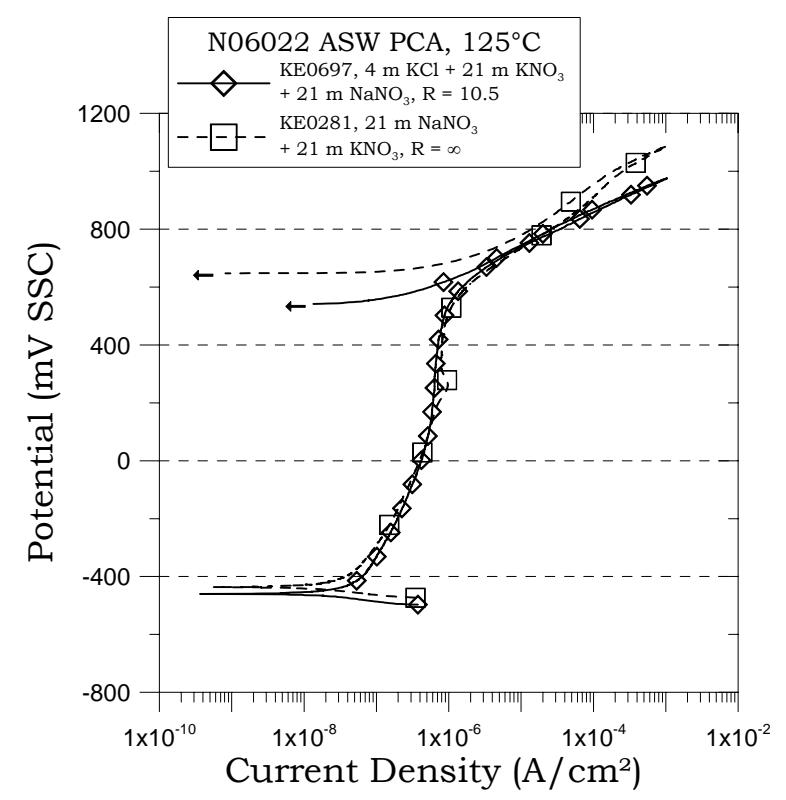

Figure 9. CPP of Alloy 22 in brines at $125^{\circ} \mathrm{C}$

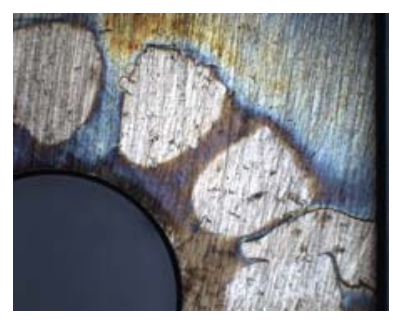

KE0697, $R=10.5$

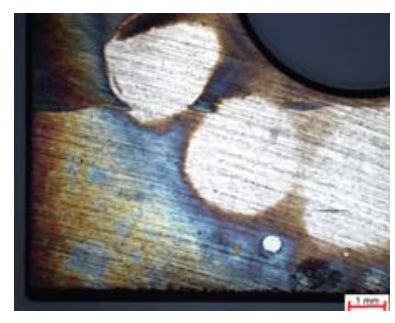

$K E 0281, R=\infty$
Figure 10. No localized corrosion after CPP in high nitrate brines at $125^{\circ} \mathrm{C}$ 


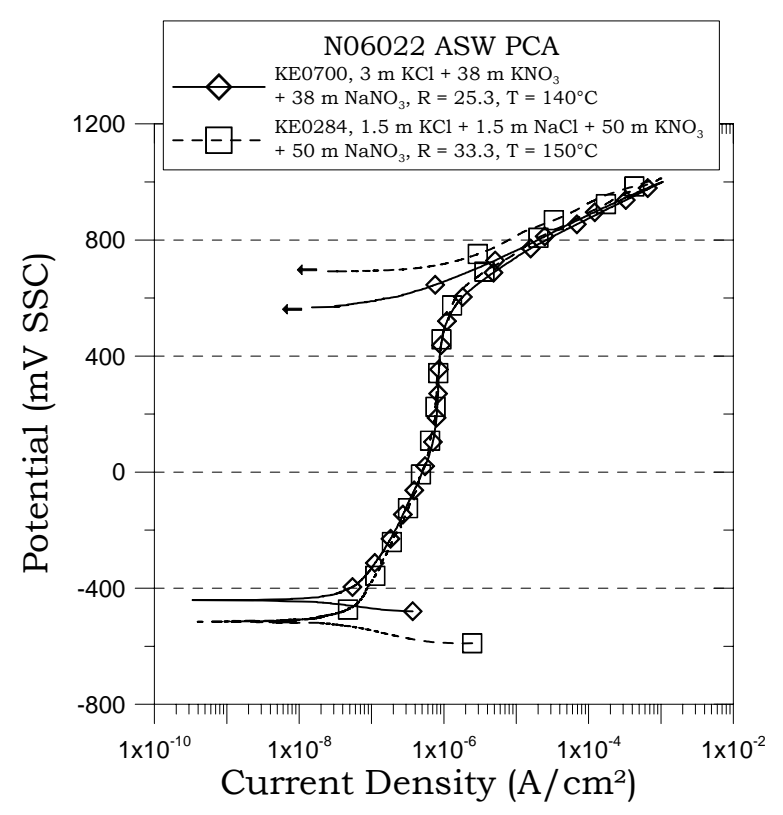

Figure 11. CPP of Alloy 22 at $140^{\circ} \mathrm{C}$ and $150^{\circ} \mathrm{C}$

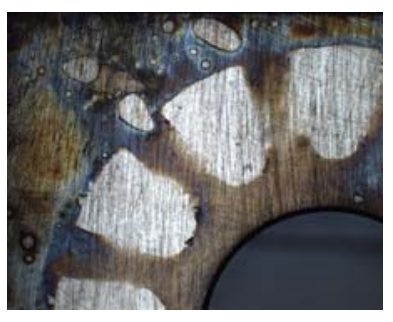

$\mathrm{KE0700,} \mathrm{R}=\mathbf{2 5 . 3}$

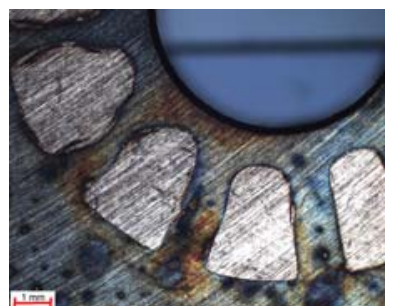

KE0284, $R=33.3$
Figure 12. No localized corrosion after CPP in high nitrate brines at $140^{\circ} \mathrm{C}$ and $150^{\circ} \mathrm{C}$

Figure 14 shows all the repassivation potentials at $110^{\circ} \mathrm{C}$ as a function of the ratio $\mathrm{R}$. It is apparent that the repassivation potentials were higher than $600 \mathrm{mV}$ for $\mathrm{R}$ values between 10.5 and 42 . None of the specimens tested in these high nitrate solutions suffered crevice corrosion (Table 2).

Figure 15 shows the repassivation potentials obtained at $125^{\circ} \mathrm{C}$. For $\mathrm{R}$ values of 2.5 and higher, the tested specimens were free from localized corrosion. For specimens KE0294 and KE0299 tested in a Ca based brine at an R value of 0.5, pitting corrosion was observed. This may have been the result of the high potential applied to the specimens. In all the cases, the repassivation potentials were high, on the order of $600 \mathrm{mV}$ or higher. Figure 15 shows only repassivation potentials for $\mathrm{Ca}$ based brines at $\mathrm{R}$ less than 10 because it is not possible to prepare a stable brine at $125^{\circ} \mathrm{C}$ with an $\mathrm{R}$ value less than 10 using only $\mathrm{Na}$ and $\mathrm{K}$ salts.

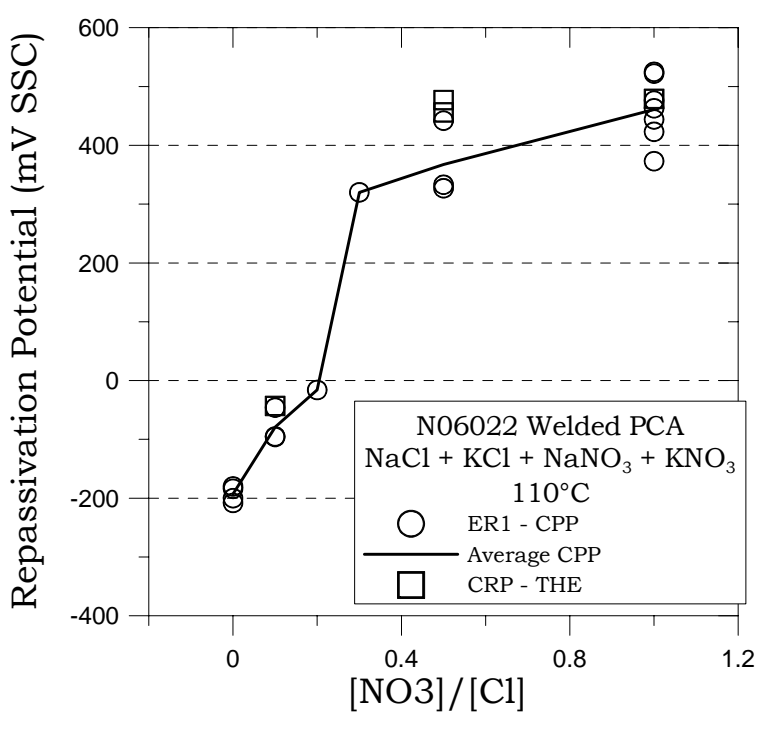

Figure 13. Repassivation potentials, $110^{\circ} \mathrm{C}, \mathrm{R} \leq 1$

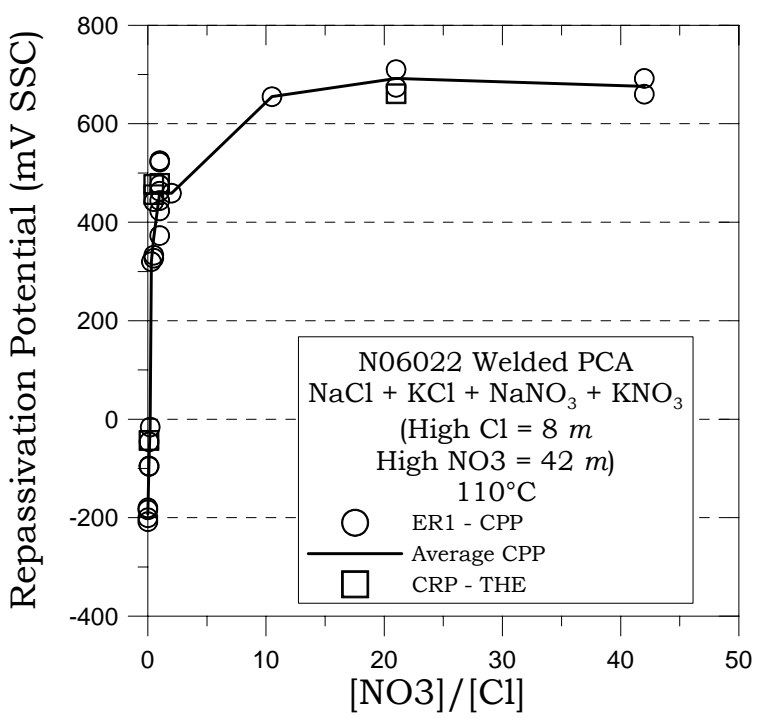

Figure 14. Repassivation potentials at $110^{\circ} \mathrm{C}$

Figure 16 shows the repassivation potentials for Alloy 22 at $140^{\circ} \mathrm{C}$ and $150^{\circ} \mathrm{C}$. Solutions that are stable at these temperatures would have values of $\mathrm{R}$ higher than 20 . It is not possible to have liquid brines at $140^{\circ} \mathrm{C}$ and $150^{\circ} \mathrm{C}$ with lower nitrate concentrations. For all the tests the repassivation potentials were higher than $600 \mathrm{mV}$ and none of the specimens suffered localized corrosion (Table 2). 


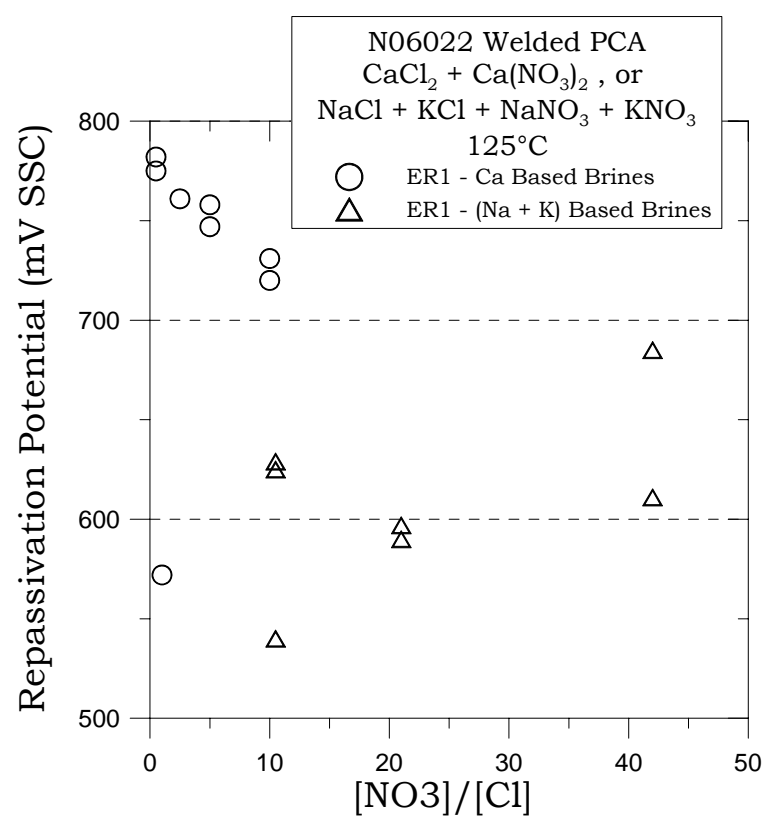

Figure 15. Repassivation potentials at $125^{\circ} \mathrm{C}$

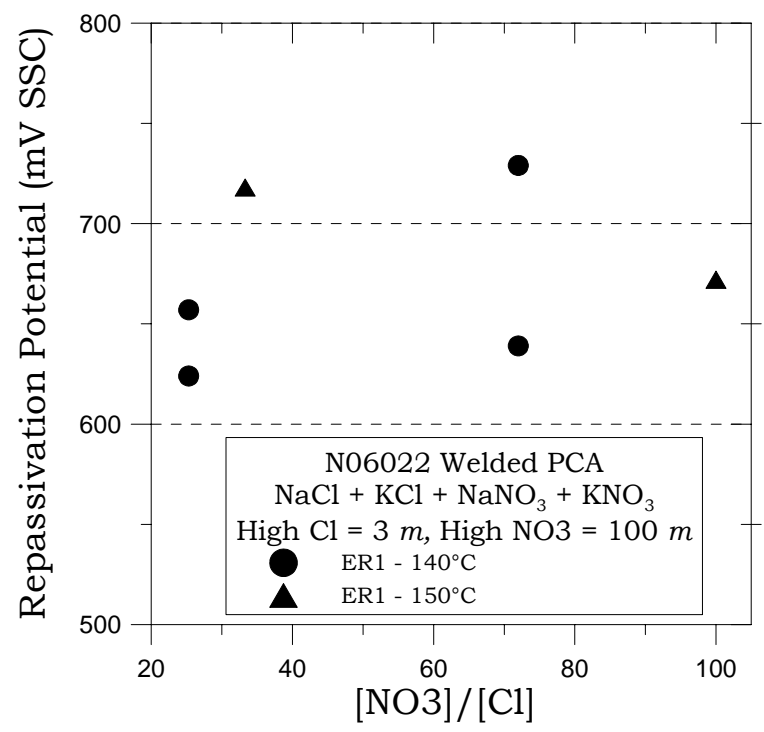

Figure 16. Repassivation potentials at $140^{\circ} \mathrm{C}$ and $150^{\circ} \mathrm{C}$

\section{Concluding Remarks}

The dust in the desert near Yucca Mountain may contain salts such as $\mathrm{NaCl}, \mathrm{KCl}, \mathrm{NaNO}_{3}$ and $\mathrm{KNO}_{3}$. Approximately 10 percent of the dust is soluble salts. ${ }^{26}$ These salts can combine to form multi-salt assemblages which can deliquesce at temperatures well above the boiling point of water (Figure 1). ${ }^{25}$ For example a ternary salt assemblage of $\mathrm{NaCl}, \mathrm{KNO}_{3}$ and $\mathrm{NaNO}_{3}$ would form a liquid solution at ambient pressure at $150^{\circ} \mathrm{C}$ and $20 \%$ relative humidity. ${ }^{25-26}$ These solutions would contain a high concentration in nitrate, with a molar ratio $\mathrm{R}$ of nitrate over chloride higher than 1 . The higher the temperature the larger the amount of nitrate that needs to be present to cause deliquescence of the salt assemblage. In other words it is not possible to prepare an electrolyte solution that would be rich in chloride at temperatures higher than $120^{\circ} \mathrm{C} .{ }^{28}$

Current results confirmed previous findings in $\mathrm{Ca}$ based brines regarding the inhibitive effect of nitrate for localized corrosion of Alloy 22 at temperatures higher than $100^{\circ} \mathrm{C} .{ }^{24}$ Nitrate will inhibit localized corrosion when it is present in ratios $\mathrm{R}=0.5$ to 2 and higher. The minimum ratio for total inhibition may be dependent on the temperature and the base concentration of chloride. Brines with values of $\mathrm{R}$ lower than 2 can be liquid only at temperatures below approximately $120^{\circ} \mathrm{C}$. Current results support the theory that any brine that may form via deliquescence at temperatures higher than approximately $120^{\circ} \mathrm{C}$ will not induce crevice corrosion in Alloy 22. The current results were obtained by forcing the alloy to corrode by artificial polarization and using a large volume of brine (fully immersed specimens). In the natural emplacement site the amount of brine will be limited and polarization may only occur naturally, for example, via the reduction of oxygen in the air.

\section{CONCLUSIONS}

Nitrate is an inhibitor for localized corrosion at ratios $R$ on the order of 0.5 to 2 and higher

The inhibitive effect of nitrate is valid at all the tested conditions from $90^{\circ} \mathrm{C}$ to $150^{\circ} \mathrm{C}$.

Similar values of repassivation potentials were obtained using the cyclic polarization and the THE methods.

Current results in $\mathrm{Na}$ and $\mathrm{K}$ brines confirm the same high temperature anodic behavior of Alloy 22 previously reported in $\mathrm{Ca}$ brines.

\section{ACKNOWLEDGMENTS}

The authors gratefully acknowledge the technical expertise of Sean J. Felker, Kirk J. Staggs and Joseph A. Rard. This work was performed under the auspices of the U. S. Department of Energy by the University of California Lawrence Livermore National Laboratory under contract No. W-7405-Eng-48. This 
work is supported by the Yucca Mountain Project, which is part of the DOE Office of Civilian Radioactive Waste Management (OCRWM)

\section{REFERENCES}

1. ASTM International, Volume 02.04, Standard B 575 (ASTM International, 2003: West Conshohocken, PA).

2. Haynes International, "Hastelloy C-22 Alloy", Brochure H-2019E (Haynes International, 1997: Kokomo, IN).

3. R. B. Rebak in Corrosion and Environmental Degradation, Volume II, p. 69, Wiley-VCH, Weinheim, Germany (2000).

4. R. B. Rebak and P. Crook, "Nickel Alloys for Corrosive Environments," Advanced Mater. \& Proc., 157, 37, 2000

5. R. B. Rebak and P. Crook "Influence of the Environment on the General Corrosion Rate of Alloy 22," PVP-Vol 483 pp. 131-136 (ASME, 2004: New York, NY).

6. R. B. Rebak and Joe H. Payer, "Passive Corrosion Behavior of Alloy 22," ANS Conf. International High Level Radioactive Waste Management, Las Vegas 30Apr04May 2006.

7. R. B. Rebak and P. Crook "Improved Pitting and Crevice Corrosion Resistance of Nickel and Cobalt Based Alloys," ECPV 98-17, pp. 289-302 (The Electrochemical Society, 1999: Pennington York, NJ).

8. B. A. Kehler, G. O. Ilevbare and J. R. Scully, Corrosion, 1042 (2001).

9. K. J. Evans and R. B. Rebak in Corrosion Science - A Retrospective and Current Status in Honor of Robert P. Frankenthal, PV 2002-13, p. 344-354 (The Electrochemical Society, 2002: Pennington, NJ).

10. K. J. Evans, S. D. Day, G. O. Ilevbare, M. T. Whalen, K. J. King, G. A. Hust, L. L. Wong, J. C. Estill and R. B. Rebak, PVP-Vol. 467, Transportation, Storage and Disposal of Radioactive Materials - 2003, p. 55 (ASME, 2003: New York, NY).

11. Y-M. Pan, D. S. Dunn and G. A. Cragnolino in Environmentally Assisted Cracking: Predictive Methods for Risk Assessment and Evaluation of Materials, Equipment and Structures, STP 1401, pp. 273-288 (West Conshohocken, PA: ASTM 2000).

12. R. B. Rebak in Environmentally Assisted Cracking: Predictive Methods for Risk Assessment and Evaluation of Materials, Equipment and Structures, STP 1401, pp. 289300 (West Conshohocken, PA: ASTM 2000).

13. C. S. Brossia, L. Browning, D. S. Dunn, O. C. Moghissi, O. Pensado and L. Yang "Effect of Environment on the Corrosion of Waste Package and Drip Shield Materials," Publication of the Center for Nuclear Waste Regulatory Analyses (CNWRA 2001-03), September 2001.
14. D. S. Dunn, L. Yang, Y.-M. Pan and G. A. Cragnolino "Localized Corrosion Susceptibility of Alloy 22," Paper 03697 (NACE International, 2003: Houston, TX).

15. K. J. Evans, A. Yilmaz, S. D. Day, L. L. Wong, J. C. Estill and R. B. Rebak "Comparison of Electrochemical Methods to Determine Crevice Corrosion Repassivation Potential of Alloy 22 in Chloride Solutions," JOM, p. 56, January 2005.

16. G. A. Cragnolino, D. S. Dunn and Y.-M. Pan "Localized Corrosion Susceptibility of Alloy 22 as a Waste Package Container Material," Scientific Basis for Nuclear Waste Management XXV, Vol. 713 (Materials Research Society 2002: Warrendale, PA).

17. D. S. Dunn and C. S. Brossia "Assessment of Passive and Localized Corrosion Processes for Alloy 22 as a HighLevel Nuclear Waste Container Material," Paper 02548 (NACE International, 2002: Houston, TX).

18. J. H. Lee, T. Summers and R. B. Rebak "A Performance Assessment Model for Localized Corrosion Susceptibility of Alloy 22 in Chloride Containing Brines for High Level Nuclear Waste Disposal Container," Paper 04692 (NACE International, 2004: Houston, TX).

19. D. S. Dunn, L. Yang, C. Wu and G. A. Cragnolino, Material Research Society Symposium, Spring 2004, San Francisco, Proc. Vol 824 (MRS, 2004: Warrendale, PA)

20. D. S. Dunn, Y.-M. Pan, L. Yang and G. A Cragnolino and $\mathrm{X}$. He "Localized Corrosion Resistance and Mechanical Properties of Alloy 22 Waste Package Outer Containers" JOM, January 2005, pp 49-55.

21. R. B. Rebak, "Factors Affecting the Crevice Corrosion Susceptibility of Alloy 22," Paper 05610, Corrosion/2005 (NACE International, 2005: Houston, TX)

22. D. S. Dunn, Y.-M. Pan, L. Yang and G. A Cragnolino, Corrosion, 61, 11, 1076, 2005

23. G. O. Ilevbare, K. J. King, S. R. Gordon, H. A. Elayat, G. E. Gdowski and T. S. E. Summers, Journal of The Electrochemical Society, 152, 12, B547-B554, 2005

24. G. O. Ilevbare, R. A. Etien, J. C. Estill, G. A. Hust, A. Yilmaz, M. L. Stuart, and R. B. Rebak, "Anodic Behavior of Alloy 22 in High Nitrate Brines at temperatures higher than $100^{\circ} \mathrm{C}$," Paper PVP2006-ICPVT11-93423 in Proceedings of the 2006 ASME Pressure Vessels and Piping Division Conference, July 23-27, 2006, Vancouver, BC, Canada.

25. J. A. Rard, K. J. Staggs, S. D. Day and S. A. Carroll, "Boiling Temperature and Reversed Deliquescence Relative Humidity Measurements for Mineral Assemblages in the $\mathrm{NaCl}+\mathrm{NaNO}_{3}+\mathrm{KNO}_{3}+\mathrm{Ca}\left(\mathrm{NO}_{3}\right)_{2}+\mathrm{H}_{2} \mathrm{O}$ System" J. Solution Chemistry, 35, 1187-1215, 2006

26. C. R. Bryan, "Evolution of Waste Package Environments in a Repository at Yucca Mountain," presented the Nuclear Waste Technical Review Board Workshop on Localized Corrosion, 25-26 September 2006, Las Vegas, Nevada (http://www.nwtrb.gov/meetings/overheads.html). 
27. ASTM International, Volume 03.02, Standards G 5, G 48, G 59, G 61, G 102 (ASTM International, 2003: West Conshohocken, PA).

28. R. B. Rebak, "Newer Alloy 22 Data and Their Relevance to High-Temperature Localized Corrosion," presented the
Nuclear Waste Technical Review Board Workshop on Localized Corrosion, 25-26 September 2006, Las Vegas, Nevada (http://www.nwtrb.gov/meetings/overheads.html).

Table 2. Tested Conditions and Characteristic Potentials (in $\mathrm{mV}, \mathrm{SSC}$ ) from the Cyclic Polarization Curves (CPP) and the Tsujikawa-Hisamatsu Electrochemical (THE) tests

\begin{tabular}{|c|c|c|c|c|c|c|c|c|c|c|c|}
\hline Specimen & Solution & $\begin{array}{c}\text { Temp. } \\
\left({ }^{\circ} \mathrm{C}\right)\end{array}$ & {$\left[\begin{array}{l}\mathrm{NO}_{3}^{-} \\
{\left[\mathrm{Cl}^{-}\right.}\end{array}\right]$} & Ecorr & $\begin{array}{l}\text { E20 } \\
\text { CPP }\end{array}$ & $\begin{array}{l}\text { E200 } \\
\text { CPP }\end{array}$ & $\begin{array}{l}\text { ER10 } \\
\text { CPP }\end{array}$ & $\begin{array}{l}\text { ER1 } \\
\text { CPP }\end{array}$ & $\begin{array}{l}\text { ERCO } \\
\text { CPP }\end{array}$ & $\begin{array}{l}\text { CRP } \\
\text { THE }\end{array}$ & Results \\
\hline KE0592 & $\begin{array}{l}4 \mathrm{~m} \mathrm{KCl}+4 \mathrm{~m} \mathrm{NaCl}+0.4 \mathrm{~m} \mathrm{KNO}_{3} \\
+0.4 \mathrm{~m} \mathrm{NaNO}_{3}\end{array}$ & 90 & 0.1 & -123 & 727 & 817 & 684 & 571 & 570 & & $\mathrm{CC}$ \\
\hline KE0688 & $\begin{array}{l}4 \mathrm{~m} \mathrm{KCl}+4 \mathrm{~m} \mathrm{NaCl}+0.4 \mathrm{~m} \mathrm{KNO}_{3} \\
+0.4 \mathrm{~m} \mathrm{NaNO}_{3}\end{array}$ & 90 & 0.1 & -501 & 684 & 805 & 33 & -63 & -82 & & $\mathrm{CC}$ \\
\hline KE0579 & $\begin{array}{l}4 \mathrm{~m} \mathrm{KCl}+4 \mathrm{~m} \mathrm{NaCl}+0.4 \mathrm{~m} \mathrm{KNO}_{3} \\
+0.4 \mathrm{~m} \mathrm{NaNO} 3\end{array}$ & 90 & 0.1 & -482 & 676 & 816 & 83 & -53 & -80 & & $\mathrm{CC}$ \\
\hline KE0590 & $\begin{array}{l}4 \mathrm{~m} \mathrm{KCl}+4 \mathrm{~m} \mathrm{NaCl}+0.8 \mathrm{~m} \mathrm{KNO}_{3} \\
+0.8 \mathrm{~m} \mathrm{NaNO}_{3}\end{array}$ & 90 & 0.2 & -493 & 695 & 819 & 647 & 405 & & & $\mathrm{CC}$ \\
\hline KE0693 & $\begin{array}{l}4 \mathrm{~m} \mathrm{KCl}+4 \mathrm{~m} \mathrm{NaCl}+0.8 \mathrm{~m} \mathrm{KNO}_{3} \\
+0.8 \mathrm{~m} \mathrm{NaNO}_{3}\end{array}$ & 90 & 0.2 & -498 & 686 & 821 & 630 & 384 & & & $\mathrm{CC}$ \\
\hline KE0279 & $\begin{array}{l}4 \mathrm{~m} \mathrm{KCl}+4 \mathrm{~m} \mathrm{NaCl}+0.8 \mathrm{~m} \mathrm{KNO}_{3} \\
+0.8 \mathrm{~m} \mathrm{NaNO}_{3}\end{array}$ & 90 & 0.2 & -480 & & & & & & $\mathrm{~N} / \mathrm{A}$ & $\mathrm{CC}$ \\
\hline KE0288 & $\begin{array}{l}4 \mathrm{~m} \mathrm{KCl}_{+} 4 \mathrm{~m} \mathrm{NaCl}+2 \mathrm{~m} \mathrm{KNO}_{3}+ \\
2 \mathrm{~m} \mathrm{NaNO}_{3}\end{array}$ & 90 & 0.5 & -454 & & & & & & 555 & $\mathrm{CC}$ \\
\hline KE0689 & $4 \mathrm{~m} \mathrm{KCl}+4 \mathrm{~m} \mathrm{NaCl}$ & 110 & 0 & -557 & 85 & 141 & -123 & -200 & -223 & & $\mathrm{CC}$ \\
\hline KE0574 & $\begin{array}{l}4 \mathrm{~m} \mathrm{KCl}+4 \mathrm{~m} \mathrm{NaCl}(+0.0001 \mathrm{~m} \\
\mathrm{HCl})\end{array}$ & 110 & 0 & -413 & 48 & 102 & -135 & -208 & -222 & & CC \\
\hline KE0691 & $4 \mathrm{~m} \mathrm{KCl}+4 \mathrm{~m} \mathrm{NaCl}$ & 110 & 0 & -555 & 49 & 115 & -101 & -184 & -210 & & $\mathrm{CC}$ \\
\hline KE0588 & $4 \mathrm{~m} \mathrm{CaCl}_{2}$ & 110 & 0 & -321 & 34 & 67 & -123 & -180 & -243 & & $\mathrm{CC}$ \\
\hline KE0687 & $\begin{array}{l}4 \mathrm{~m} \mathrm{KCl}+4 \mathrm{~m} \mathrm{NaCl}+0.4 \mathrm{~m} \mathrm{KNO}_{3} \\
+0.4 \mathrm{~m} \mathrm{NaNO}_{3}\end{array}$ & 110 & 0.1 & -522 & 361 & 516 & -3 & -46 & -50 & & $\mathrm{CC}$ \\
\hline KE0692 & $\begin{array}{l}4 \mathrm{~m} \mathrm{KCl}+4 \mathrm{~m} \mathrm{NaCl}+0.4 \mathrm{~m} \mathrm{KNO}_{3} \\
+0.4 \mathrm{~m} \mathrm{NaNO}_{3}\end{array}$ & 110 & 0.1 & -396 & 553 & 778 & -26 & -95 & -103 & & $\mathrm{CC}$ \\
\hline KE0573 & $\begin{array}{l}4 \mathrm{~m} \mathrm{KCl}+4 \mathrm{~m} \mathrm{NaCl}+0.4 \mathrm{~m} \mathrm{KNO}_{3} \\
+0.4 \mathrm{~m} \mathrm{NaNO}_{3}(+0.0001 \mathrm{~m} \mathrm{HCl})\end{array}$ & 110 & 0.1 & -375 & 511 & 738 & -39 & -96 & -106 & & $\mathrm{CC}$ \\
\hline KE0276 & $\begin{array}{l}4 \mathrm{~m} \mathrm{KCl}+4 \mathrm{~m} \mathrm{NaCl}+0.4 \mathrm{~m} \mathrm{KNO}_{3} \\
+0.4 \mathrm{~m} \mathrm{NaNO}_{3}\end{array}$ & 110 & 0.1 & -521 & & & & & & -43 & CC \\
\hline KE0589 & $\begin{array}{l}4 \mathrm{~m} \mathrm{KCl}+4 \mathrm{~m} \mathrm{NaCl}_{+} 0.8 \mathrm{~m} \mathrm{KNO}_{3} \\
+0.8 \mathrm{~m} \mathrm{NaNO}_{3}\end{array}$ & 110 & 0.2 & -534 & 469 & 746 & 375 & -16 & -44 & & CC \\
\hline KE0591 & $\begin{array}{l}4 \mathrm{~m} \mathrm{KCl}+4 \mathrm{~m} \mathrm{NaCl}+1.2 \mathrm{~m} \mathrm{KNO}_{3} \\
+1.2 \mathrm{~m} \mathrm{NaNO}_{3}\end{array}$ & 110 & 0.3 & -562 & 589 & 769 & 481 & 320 & 258 & & No CC \\
\hline KE0278 & $\begin{array}{l}4 \mathrm{~m} \mathrm{KCl}+4 \mathrm{~m} \mathrm{NaCl}+1.2 \mathrm{~m} \mathrm{KNO}_{3} \\
+1.2 \mathrm{~m} \mathrm{NaNO}_{3}\end{array}$ & 110 & 0.3 & -500 & & & & & & & \\
\hline
\end{tabular}


Table 2 - Continued - 1

\begin{tabular}{|c|c|c|c|c|c|c|c|c|c|c|c|}
\hline KE0572 & $\begin{array}{l}4 \mathrm{~m} \mathrm{KCl}^{+} 4 \mathrm{~m} \mathrm{NaCl}_{2} 2 \mathrm{~m} \mathrm{KNO}_{3}+ \\
2 \mathrm{~m} \mathrm{NaNO}_{3}(+0.0001 \mathrm{~m} \mathrm{HCl})\end{array}$ & 110 & 0.5 & -304 & 668 & 780 & 601 & 442 & 446 & & CC-II \\
\hline KE0580 & $\begin{array}{l}4 \mathrm{~m} \mathrm{KCl}_{+} 4 \mathrm{~m} \mathrm{NaCl}+2 \mathrm{~m} \mathrm{KNO}_{3}+ \\
2 \mathrm{~m} \mathrm{NaNO}_{3}\end{array}$ & 110 & 0.5 & -522 & 621 & 794 & 570 & 327 & & & No CC \\
\hline KE0277 & $\begin{array}{l}4 \mathrm{~m} \mathrm{KCl}+4 \mathrm{~m} \mathrm{NaCl}+2 \mathrm{~m} \mathrm{KNO}_{3}+ \\
2 \mathrm{~m} \mathrm{NaNO}_{3}\end{array}$ & 110 & 0.5 & -482 & & & & & & 456 & CC \\
\hline KE0289 & $\begin{array}{l}4 \mathrm{~m} \mathrm{KCl}_{+} 4 \mathrm{~m} \mathrm{NaCl}+2 \mathrm{~m} \mathrm{KNO}_{3}+ \\
2 \mathrm{~m} \mathrm{NaNO}_{3}\end{array}$ & 110 & 0.5 & -514 & & & & & & 477 & $\mathrm{CC}$ \\
\hline KE0287 & $\begin{array}{l}4 \mathrm{~m} \mathrm{KCl}_{+} 4 \mathrm{~m} \mathrm{NaCl}+2 \mathrm{~m} \mathrm{KNO}_{3}+ \\
2 \mathrm{~m} \mathrm{NaNO}_{3}\end{array}$ & 110 & 0.5 & -491 & 622 & & 543 & 333 & 337 & & $\mathrm{~N} / \mathrm{A}$ \\
\hline KE0690 & $\begin{array}{l}3 \mathrm{~m} \mathrm{KCl}+3 \mathrm{~m} \mathrm{NaCl}+3 \mathrm{~m} \mathrm{KNO}_{3}+ \\
3 \mathrm{~m} \mathrm{NaNO}_{3}\end{array}$ & 110 & 1 & -545 & 576 & 791 & 571 & 373 & & & No CC \\
\hline KE0571 & $\begin{array}{l}3 \mathrm{~m} \mathrm{KCl}+3 \mathrm{~m} \mathrm{NaCl}+3 \mathrm{~m} \mathrm{KNO}_{3}+ \\
3 \mathrm{~m} \mathrm{NaNO}_{3}(+0.0001 \mathrm{~m} \mathrm{HCl})\end{array}$ & 110 & 1 & 194 & 651 & 770 & 581 & 444 & 330 & & CC-II \\
\hline KE0575 & $\begin{array}{l}3 \mathrm{~m} \mathrm{KCl}+3 \mathrm{~m} \mathrm{NaCl}+3 \mathrm{~m} \mathrm{KNO}_{3}+ \\
3 \mathrm{~m} \mathrm{NaNO}_{3}(+0.0001 \mathrm{~m} \mathrm{HCl})\end{array}$ & 110 & 1 & -407 & 683 & 759 & 569 & 423 & 413 & & CC-II \\
\hline KE0581 & $\begin{array}{l}3 \mathrm{~m} \mathrm{KCl}+3 \mathrm{~m} \mathrm{NaCl}+3 \mathrm{~m} \mathrm{KNO}_{3}+ \\
3 \mathrm{~m} \mathrm{NaNO}_{3}\end{array}$ & 110 & 1 & 214 & 682 & 779 & 622 & 522 & 496 & & No CC \\
\hline KE0285 & $\begin{array}{l}3 \mathrm{~m} \mathrm{KCl}+3 \mathrm{~m} \mathrm{NaCl}+3 \mathrm{~m} \mathrm{KNO}_{3}+ \\
3 \mathrm{~m} \mathrm{NaNO}_{3}\end{array}$ & 110 & 1 & -358 & 708 & & 633 & 476 & 481 & & $\mathrm{~N} / \mathrm{A}$ \\
\hline KE0308 & $\begin{array}{l}3 \mathrm{~m} \mathrm{KCl}+3 \mathrm{~m} \mathrm{NaCl}+3 \mathrm{~m} \mathrm{KNO}_{3}+ \\
3 \mathrm{~m} \mathrm{NaNO}_{3}\end{array}$ & 110 & 1 & -485 & & & & & & 479 & CC-II \\
\hline KE0291 & $\begin{array}{l}4 \mathrm{~m} \mathrm{CaCl}_{2}+4 \mathrm{~m} \mathrm{KNO}_{3}+4 \mathrm{~m} \\
\mathrm{NaNO}_{3}\end{array}$ & 110 & 1 & -371 & 700 & 864 & 643 & 463 & & & CC-II \\
\hline KE0301 & $\begin{array}{l}4 \mathrm{~m} \mathrm{CaCl}_{2}+4 \mathrm{~m} \mathrm{KNO}_{3}+4 \mathrm{~m} \\
\mathrm{NaNO}_{3}\end{array}$ & 110 & 1 & -384 & 713 & 867 & 673 & 525 & & & No CC \\
\hline KE0286 & $\begin{array}{l}3 \mathrm{~m} \mathrm{KCl}+3 \mathrm{~m} \mathrm{NaCl}+6 \mathrm{~m} \mathrm{KNO}_{3}+ \\
6 \mathrm{~m} \mathrm{NaNO}_{3}\end{array}$ & 110 & 2 & -431 & 696 & & 644 & 459 & 461 & & $\mathrm{~N} / \mathrm{A}$ \\
\hline KE0582 & $\begin{array}{l}4 \mathrm{~m} \mathrm{KCl}+21 \mathrm{~m} \mathrm{KNO}_{3}+21 \mathrm{~m} \\
\mathrm{NaNO}_{3}(+0.0001 \mathrm{~m} \mathrm{HCl})\end{array}$ & 110 & 10.5 & -106 & 799 & 907 & 764 & 655 & 615 & & No CC \\
\hline KE0695 & $\begin{array}{l}2 \mathrm{~m} \mathrm{KCl}+21 \mathrm{~m} \mathrm{KNO}_{3}+21 \mathrm{~m} \\
\mathrm{NaNO}_{3}\end{array}$ & 110 & 21 & -233 & 828 & 934 & 779 & 674 & 644 & & No CC \\
\hline KE0583 & $\begin{array}{l}2 \mathrm{~m} \mathrm{KCl}+21 \mathrm{~m} \mathrm{KNO}_{3}+21 \mathrm{~m} \\
\left.\mathrm{NaNO}_{3}+0.0001 \mathrm{~m} \mathrm{HCl}\right)\end{array}$ & 110 & 21 & -296 & 816 & 926 & 760 & 710 & 661 & & No CC \\
\hline KE0309 & $\begin{array}{l}2 \mathrm{~m} \mathrm{KCl}+21 \mathrm{~m} \mathrm{KNO}_{3}+21 \mathrm{~m} \\
\mathrm{NaNO}_{3}\end{array}$ & 110 & 21 & -382 & & & & & & 661 & No CC \\
\hline KE0696 & $\begin{array}{l}1 \mathrm{~m} \mathrm{KCl}+21 \mathrm{~m} \mathrm{KNO}_{3}+21 \mathrm{~m} \\
\mathrm{NaNO}_{3}\end{array}$ & 110 & 42 & -427 & 845 & 990 & 794 & 692 & 797 & & No CC \\
\hline KE0584 & $\begin{array}{l}1 \mathrm{~m} \mathrm{KCl}^{\mathrm{K}}+21 \mathrm{~m} \mathrm{KNO}_{3}+21 \mathrm{~m} \\
\mathrm{NaNO}_{3}(+0.0001 \mathrm{~m} \mathrm{HCl}) \\
\end{array}$ & 110 & 42 & -324 & 829 & 960 & 781 & 660 & 783 & & No CC \\
\hline KE0290 & $7 \mathrm{~m} \mathrm{KNO}_{3}+7 \mathrm{~m} \mathrm{NaNO}_{3}$ & 110 & $\infty$ & -373 & 619 & & 464 & 393 & 403 & & $\mathrm{~N} / \mathrm{A}$ \\
\hline KE0280 & $21 \mathrm{~m} \mathrm{KNO}_{3}+21 \mathrm{~m} \mathrm{NaNO}_{3}$ & 110 & $\infty$ & -361 & 855 & 1038 & 861 & 772 & & & No CC \\
\hline KE0294 & $12 \mathrm{~m} \mathrm{CaCl}_{2}+6 \mathrm{~m} \mathrm{Ca}\left(\mathrm{NO}_{3}\right)_{2}$ & 125 & 0.5 & -15 & 949 & 1061 & 806 & 782 & 795 & & $L C-P C$ \\
\hline
\end{tabular}


Table 2 - Continued - 2

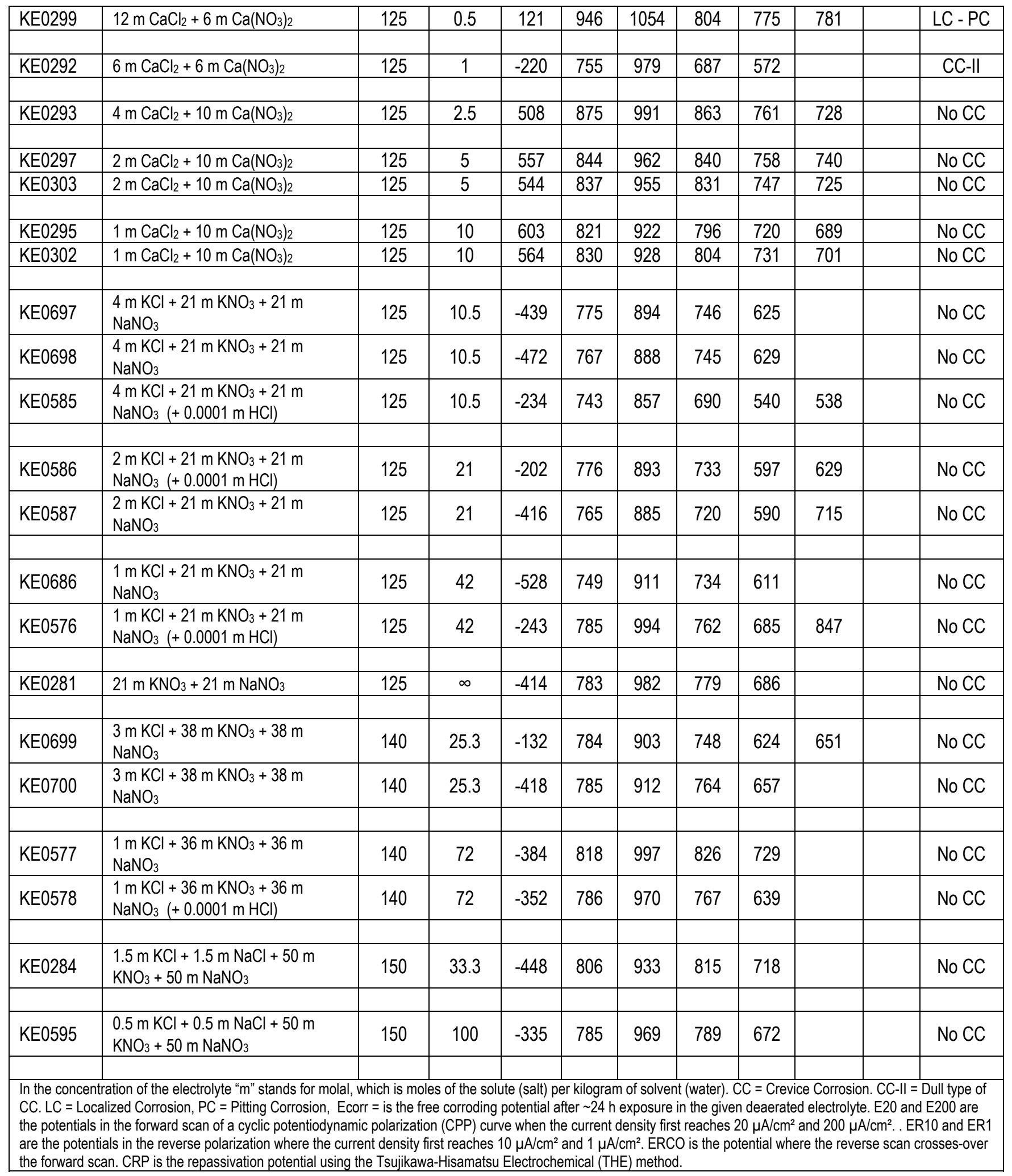

